\title{
Rancang Bangun Prototipe Alat Angkut Helikopter Berbasis Arduino
}

\author{
Evaristus Chandler Sunarto ${ }^{1}$, Bekti Yulianti ${ }^{1}$
}

\begin{abstract}
The development of ground support equipment in the aviation world is increasingly advanced and cannot be separated from various problems in its operation on helicopters. Ground support is a supporting tool needed to help the performance of helicopters when aircraft maintenance is carried out in the work area within the airport or while in the hangar. Some obstacles to ground support faced include holding the load, maintaining the balance of the helicopter during the towing / pushback process, in the event that the air traffic guide will delay the towing / pushback process to cross the runway to overcome this problem, the prototype of Arduino transport equipment was designed as the main controller which is controlled by an Android smartphone via a Bluetooth connection. The prototype was designed using two DC motors that function as movers and steering so that they can move forward, backward, turn and stop. from the results of testing the prototype, the maximum PWM speed conditions required are 255 , the input voltage on both DC motors is 7.32 Volt will produce a 76.8 RPM rotation on motor 1 and produce a 76.4 RPM rotation on the motor 2 . At speed conditions minimum PWM required is 90, then the input voltage on both DC motors is 5.77 Volt will produce 63.9 RPM rotation on motors 1 and 64.1 RPM on motor 2.
\end{abstract}

KEYWORDS: ground support, PWM, angular velocity.

\begin{abstract}
ABSTRAK : Perkembangan peralatan ground support di dunia penerbangan semakin maju dan tidak dapat dipisahkan dari berbagai masalah dalam pengoperasiannya pada helikopter. Ground support merupakan alat penunjang yang dibutuhkan untuk membantu kinerja dari helikopter saat dilakukan perawatan pesawat udara di area kerjanya dalam lingkup bandara maupun saat berada didalam hanggar. Beberapa kendala ground support yang dihadapi antara lain menahan beban, menjaga keseimbangan helikopter selama prosestowing/pushback berlangsung, pada kondisi notam di mana pemandu lalu lintas udara akan menunda proses towing/pushback untuk menyebrang landasan pacu, untuk mengatasi masalah tersebut, maka dirancang prototipe alat angkut dengan arduino sebagai pengendali utamayang dikendalikan dengan smartphone android melalui koneksi bluetooth. Prototipe dirancang menggunakan dua motor DC yang berfungsi sebagai penggerak dan steering agar dapat bergerak maju, mundur, berbelok dan berhenti. Dari hasil pengujian prototipe, kondisi kecepatan maksimum PWM yang dibutuhkan sebanyak 255, maka tegangan input pada kedua motor DC adalah 7,32 Volt akan menghasilkan putaran 76,8 RPM pada motor 1 dan menghasilkan putaran 76,4 RPM pada motor 2. Pada kondisi kecepatan minimum PWM yang dibutuhkan sebanyak 90, maka tegangan input pada kedua motor DC adalah 5,77 Volt akan menghasilkan putaran 63,9 RPM pada motor 1 dan 64,1 RPM pada motor 2.
\end{abstract}

KATA KUNCI :ground support, PWM, kecepatan sudut.

\section{PENDAHULUAN}

$\mathrm{P}$ erkembangan peralatan ground support di dunia penerbangan semakin maju dan tidak dapat dipisahkan dari berbagai masalah dalam pengoperasiannya pada helikopter. Ground support merupakan alat penunjang yang dibutuhkan untuk membantu kinerja dari helikopter saat dilakukan perawatan pesawat udara di area kerjanya.

Helikopter yang terbang dari bandara ke lokasi yang di tuju harus memenuhi prosedur standar dimana saat pengoperasiannya mengharuskan operator helikopter untuk menaikan dan menurunkan penumpang pada lokasi parkir helikopter yang telah ditentukan oleh pemandu lalu lintas udara di bandara sehingga menuntut setiap operator helikopter yang berada di hanggar melakukan metode towing/pushback menggunakan tow car yang berfungsi sebagai truk pendorong berbentuk rendah agar tidak menyentuh bagian hidung helikopter. Cara mendorongnya dilakukan dengan menyambungkan sebuah batang logam yang disebut tow bar diantara helikopter dan truk pendorong. Bentuk tow bar ini berbeda-beda untuk setiap jenis helikopter.

Metode towing/pushback yang diterapkan pada helikopter tipe landing skid yang sekarang ini sangat beresiko menyebabkan kelelahan seorang teknisi pesawat menahan dan menyeimbangkan beban helikopter yang berangsur lama saat proses towing/pushback ke arah terminal bandara maupun kembali ke hanggar, mengingat jarak pemindahan helikopter yang jauh di tambah lagi dengan kondisi saat menyebrangi landasan pacu akan tertahan yang karena padatnya aktivitas lepas landas dan pendaratan dibandara.

Oleh karena itu pentingnya mengembangkan metode towing/pushback konvensional yang sekarang ini dengan membuat prototipe alat angkut helikopter tipe landing skid berbasis arduino sebagai pengendali utama pada sistem untuk mengontrol motor DC dengan android, yang mana akan dijadikan sebagai alat angkut yang dikendalikan via bluetooth melalui smartphone android untuk mempermudah pekerjaan teknisi pesawat saat melakukan proses pemindahan helikopter tanpa lagi menahan dan menyeimbangkan beban helikopter.

\section{Arduino Uno}

\section{LANDASAN TEORI}

Arduino merupakan platform prototyping berbasis open source elektronik yang mudah digunakan (fleksibel) baik dari perangkat keras (hardware) maupun perangkat lunaknya (software). Arduino mempunyai

\footnotetext{
${ }^{1}$ Teknik Elektro Universitas Dirgantara Marsekal Suryadarma, Jakarta
} 
input yang dapat menerima masukan dari berbagai sensor dan outputnya sebagai pengendali seperti lampu, motor dan aktuator lainnya.

Ada dua macam software yang berada dalam lingkup arduino, yaitu aplikasi arduino IDE (Integrated Development Environment) dan sketch dalam bahasa pemrograman C. Aplikasi arduino IDE adalah aplikasi dari arduino.cc yang digunakan untuk mengelola semua hal yang berhubungan dengan arduino. Termasuk di dalamnya adalah membuat, menyimpan, memanggil file program Arduino (disebut juga 'sketch' dengan ekstensi '.ino') dan meng-upload file sketch ke mikrokontroller.

Sketch adalah program arduino dalam bahasa $\mathrm{C}$ yang harus diisikan (di-upload menggunakan arduino IDE) ke dalam IC mikrokontroller. Sebuah sketch, minimal harus memiliki dua blok program, yakni void setup \{\} untuk menginisialisasi program dan atau variabel pendukung, dan void loop \{\} yang berisikan program utama.

\section{Modul Bluetooth HC-05}

Bluetooth adalah sebagai teknologi komunikasi wireless (tanpa kabel) yang beroperasi dalam pita frekuensi 2,4 GHz unlicensed ISM (Industrial, Scientific and Medical) dengan menggunakan sebuah frequency hopping tranceiver yang mampu menyediakan layanan komunikasi data dan suara secara real-time antara hosthost bluetooth dengan jarak jangkauan layanan yang terbatas yakni sekitar 10 meter.

Seri modul bluetooth HC bisa dikenali dari nomor serinya, jika nomer serinya genap maka modul bluetooth tersebut sudah diset oleh pabrik, bekerja sebagai slave atau master dan tidak dapat diubah mode kerjanya, contoh adalah HC-06-S. Modul bluetooth ini akan bekerja sebagai bluetoothSlave dan tidak bisa diubah menjadi Master, demikian juga sebaliknya misalnya HC-04M. Default mode kerja untuk modul bluetooth HC dengan seri genap adalah sebagai Slave. Sedangkan modul bluetooth HC dengan nomer seri ganjil, misalkan HC-05, kondisi default biasanya diset sebagai mode Slave, tetapi pengguna bisa mengubahnya menjadi mode Master dengan AT Command tertentu. Penggunaan utama dari modul bluetooth ini adalah menggantikan komunikasi serial via kabel ke smartphone android.

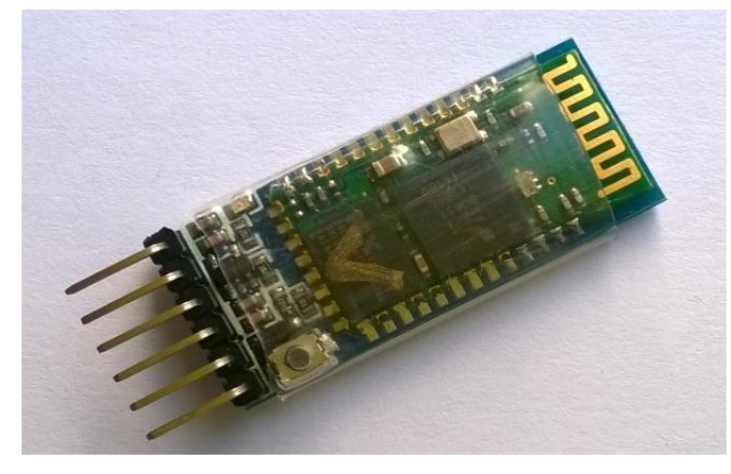

- Gambar 1.Modul Bluetooth HC-05

\section{Motor Driver Shield L293D}

IC L293D yang terdapat pada motor driver shield adalah IC yang dirancang secara khusus sebagai pengendali motor DC dan dapat dikendalikan dengan rangkaian mikrokontroller. Motor DC yang dikendalikan dengan driver IC L293D dapat dihubungkan ke ground maupun ke sumber tegangan positif karena didalam sistem driver L293D yang digunakan adalah totem pool. Dalam satu buah IC L293D terdiri dari 4 buah driver motor DC yang berdiri sendiri-sendiri. Sehingga dapat digunakan untuk membuat driver H-bridge untuk 2 buah motor DC. Modul arduino motor driver shield 2-L293D ini menggunakan dua buah IC L293D sehingga terdapat empat buah $\mathrm{H}$-bridge yang dapat digunakan mengendalikan empat buah motor DC secara dua arah dengan arus untuk setiap H-bridge ialah 0,6 A. Secara default tegangan kerja motor yang dapat dikendalikan ialah berkisar antara 4,5 Volt hingga 16 Volt.Selain motor DC, modul driver motor ini juga dapat digunakan untuk mengendalikan hingga dua buah motor stepper dan juga dua buah motor servo. 


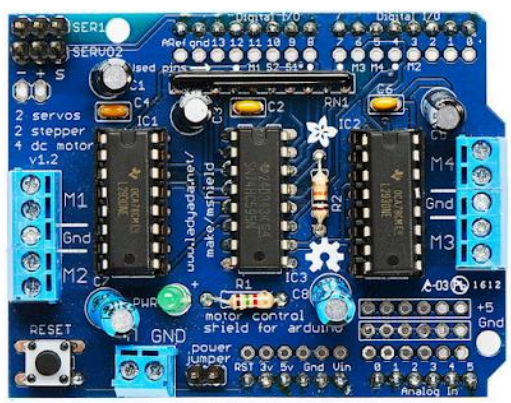

— Gambar 2.Arduino Motor DriverShield2-L293D

\section{Driver Motor H-Bridge}

$\mathrm{H}$-Bridge atau jembatan $\mathrm{H}$ adalah adalah salah satu rangkaian yangdigunakan untuk mengendalikan motor DC. Driver motor DC H-Bridgetransistor ini dapat mengendalikan arah putaran motor DC dalam 2 arah dandapat dikontrol dengan metode PWM (Pulse Width Modulation) maupunmetode sinyal logika dasar TTL (High) dan (Low).

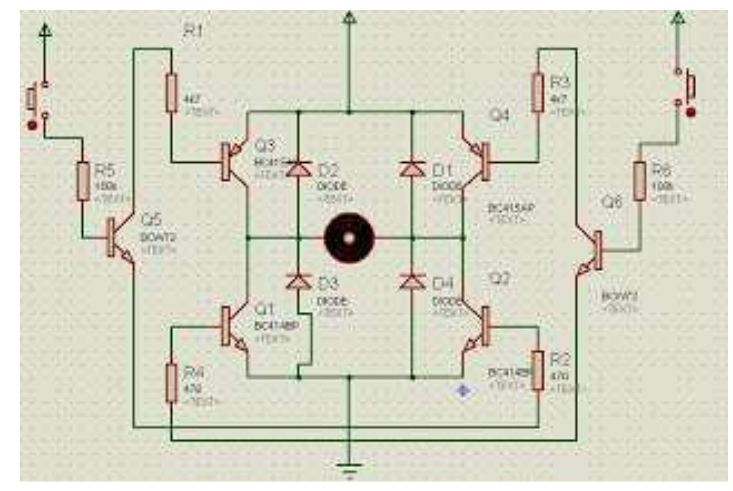

- Gambar 3. Rangkaian H-Bridge

Driver Motor DC dengan metode logika TTL (0 dan 1) atau High dan Low hanya dapat mengendalikan arah putar motor DC dalam 2 arah tanpa pengendalian kecepatan putaran (kepatan maksimum). untuk mengendalikan motor DC dalam 2 arah dengan rangkaian driver motor DC H-bridge diatas konfiguarasi kontrol pada jalur input adalah dengan memberikan input berupa logika TTL ke jalur input A dan B sebagai berikut :

1. Untuk mengendalikan arah putar searah jarum jam adalah dengan memberikan logika TTL 1 (high) pada jalur input A dan logika TTL 0 (low) pada jalur input B.

2. Untuk mengendalikan arah putar berlawanan arah jarum jam adalah dengan memberikan logika TTL 1 (high) pada jalur input B dan logika TTL 0 (low) pada jalur input $\mathrm{A}$.

Driver motor DC dengan metode PWM dapat mengendalikan arah putaran dan kecepatan motor DC menggunakan pulsa PWM yang diberikan ke jalur input A dan B, dimana konfigurasi sinyal kontrol sebagai berikut :

1. Untuk mengendalikan arah putar motor DC searah jarum jam dengan kecepatan dikendalikan pulsa PWM maka jalur input B selalu diberikan logika TTL 0 (Low) dan jalur input A diberikan pulsa PWM.

2. Untuk mengendalikan arah putar motor DC berlawanan arah jarum jam dengan kecepatan dikendalikan pulsa PWM maka jalur input A selalu diberikan logika TTL 0 (Low) dan jalur input B diberikan pulsa PWM. 


\section{Blok Diagram Sistem}

\section{PERANCANGAN ALAT}

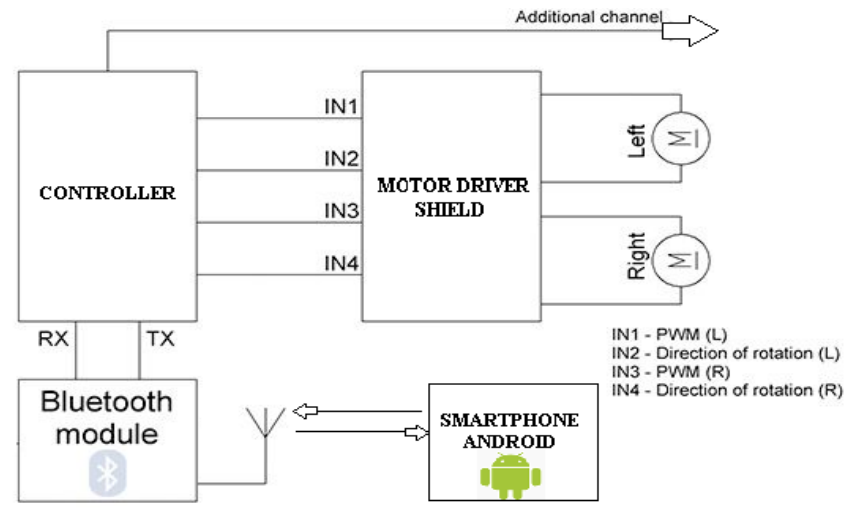

- Gambar 4. Tampilan Mekanika

Smarthphone berkomunikasi menerima dan mengirim nilai data secara interface dengan cara mengubah signal masukan dan keluaran ke modul bluetooth HC-05 sebagai penghubung komunikasi tanpa kabel ke controller yang sudah di program. Sinyal dari controller tersebut, yang berupa PWM (Pulse Width Modulation) memungkinkan pin digital dapat bernilai bulat antara 0 sampai 255 (untuk mencerminkan isyarat analog) dengan perubahan nilai dilakukan secara periodisuntuk mengatur kecepatan motor DC. Sinyal PWM ini kemudian dihubungkan ke IN-1 dan IN-3 motor driver shield yang berfungsi mengontrol secara terpisah tegangan input dan arus ke motor DC kiri dan kanan yang membutuhkan tegangan dan arus yang relatif besar dari pada arus output yang diperoleh langsung dari arduino. Sedangkan IN-2 dan IN-4 digunakan untuk mengontrol arah putaran motor DC dengan sinyal logic lowatau logic high.

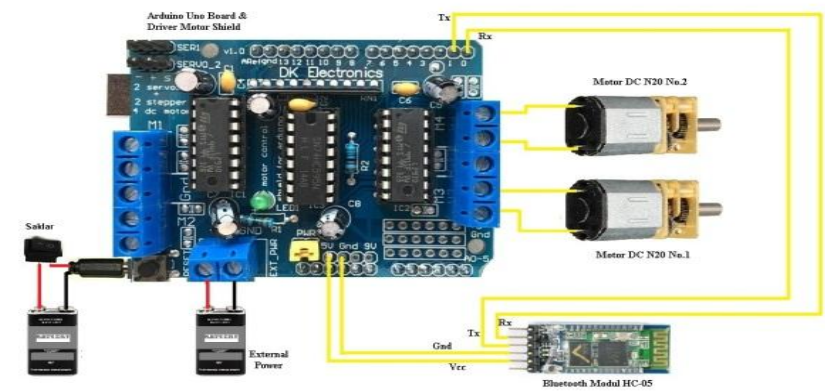

- Gambar 5. Konektivitas Modul Arduino,Motor Shield, Bluetooth HC-05 dan Motor DC

Rangkaian driver motor DC menggunakan modul motor driver shield L298akan mengatur perubahan arah putaran motor DC sesuai dengan perintah yang diberikan. Driver L298 mendapat tegangan kerja sebesar 5 Volt DC, sedangkan untuk menggerakkan motor DC dibutuhkan suplai tegangan sebesar 9 Volt DC.

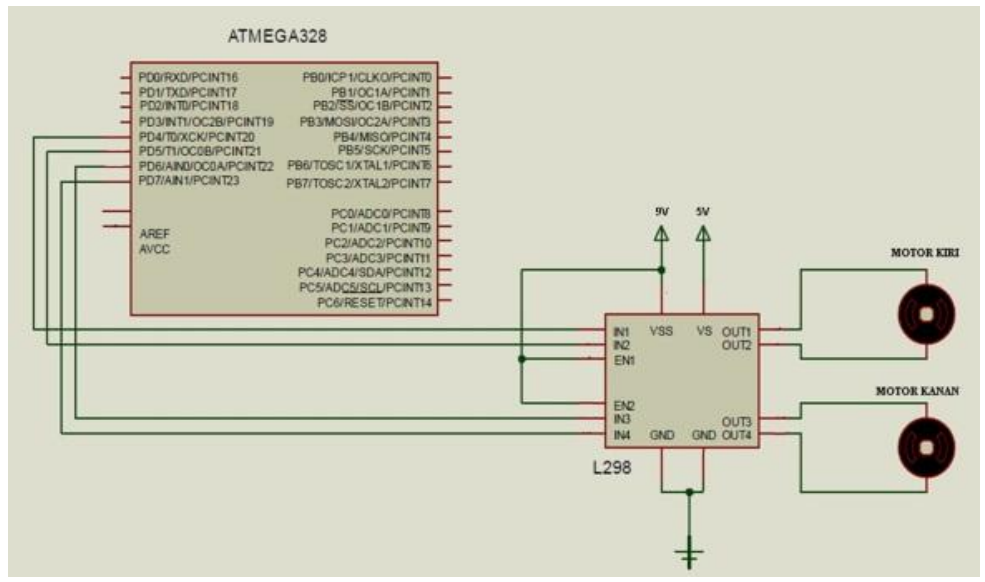

- Gambar 6. Diagram Rangkaian Motor DC 


\section{Perancangan Perangkat Keras}

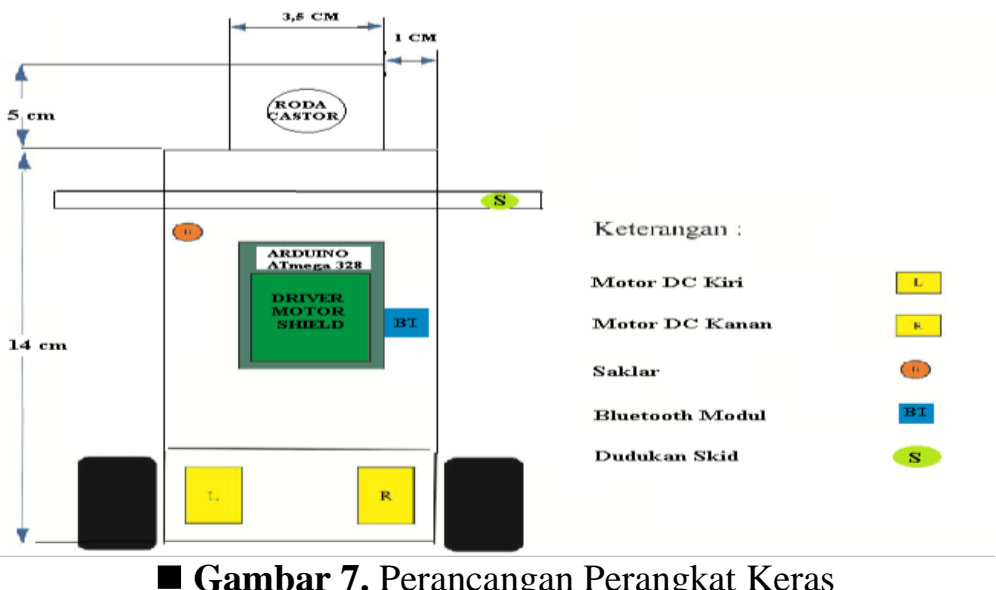

Spesifikasi alat yang digunakan adalah sebagai berikut:

1. Menggunakan dua sumber DC 9 volt yang dihasilkan dari baterai.

2. Menggunakan Arduino Uno IC Atmega328 DIP sebagai pemroses data.

3. Menggunakan saklaruntuk memutus dan menghubungkan arus listrik ke komponen motor driver shield.

4. Software Arduino Versi 1.0.6 digunakan untuk memprogram IC Arduino Atmega328.

5. Menggunakan motor driver shield L293D untuk mengendalikan arah putaran kedua motor DC tipe N20 untuk menggerakan roda.

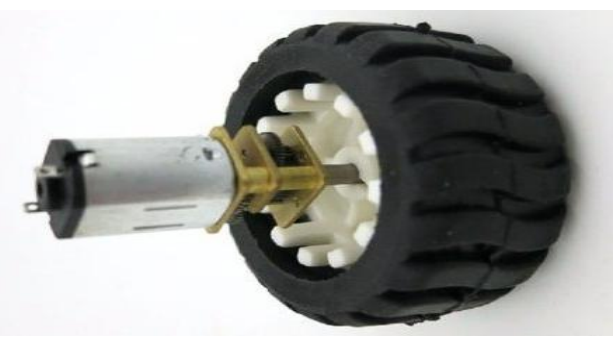

nGambar 8. Roda Penggerak

Implementasi roda penggerak dihubungkan ke shaft yang sudah di pasang motor DC terlihat seperti gambar di atas. Dengan melakukan pengukuran antara permukaan roda dengan permukaan rangka didapatkan hasil pengukuran sebesar $28 \mathrm{~mm}$. Hal ini terkesan terlalu tinggi karena jarak yang dibutuhkan antara permukaan roda dengan permukaan rangka adalah $>10 \mathrm{~mm}$ dan $<20 \mathrm{~mm}$.

Untuk memenuhi kebutuhan ini, maka penempatan kedua motor DC yang sebelumnya ada pada posisi bawah rangka diubah posisinya ke bagian atas rangka sehingga, didapatkan ukuran antara permukaan roda dengan permukaan rangka adalah $15 \mathrm{~mm}$.

\section{Algoritma Dan Flowchart Hasil Pengujian Prototipe Alat Angkut Helikopter}

Setelah melakukan pengambilan sampel pengujian kondisi pergerakan dari prototipe pada tabel 4.3.1 maka didapat hasil kerja sistem yang diperlihatkan pada algoritma dan diagram alir (flowchart) di bawah ini : 

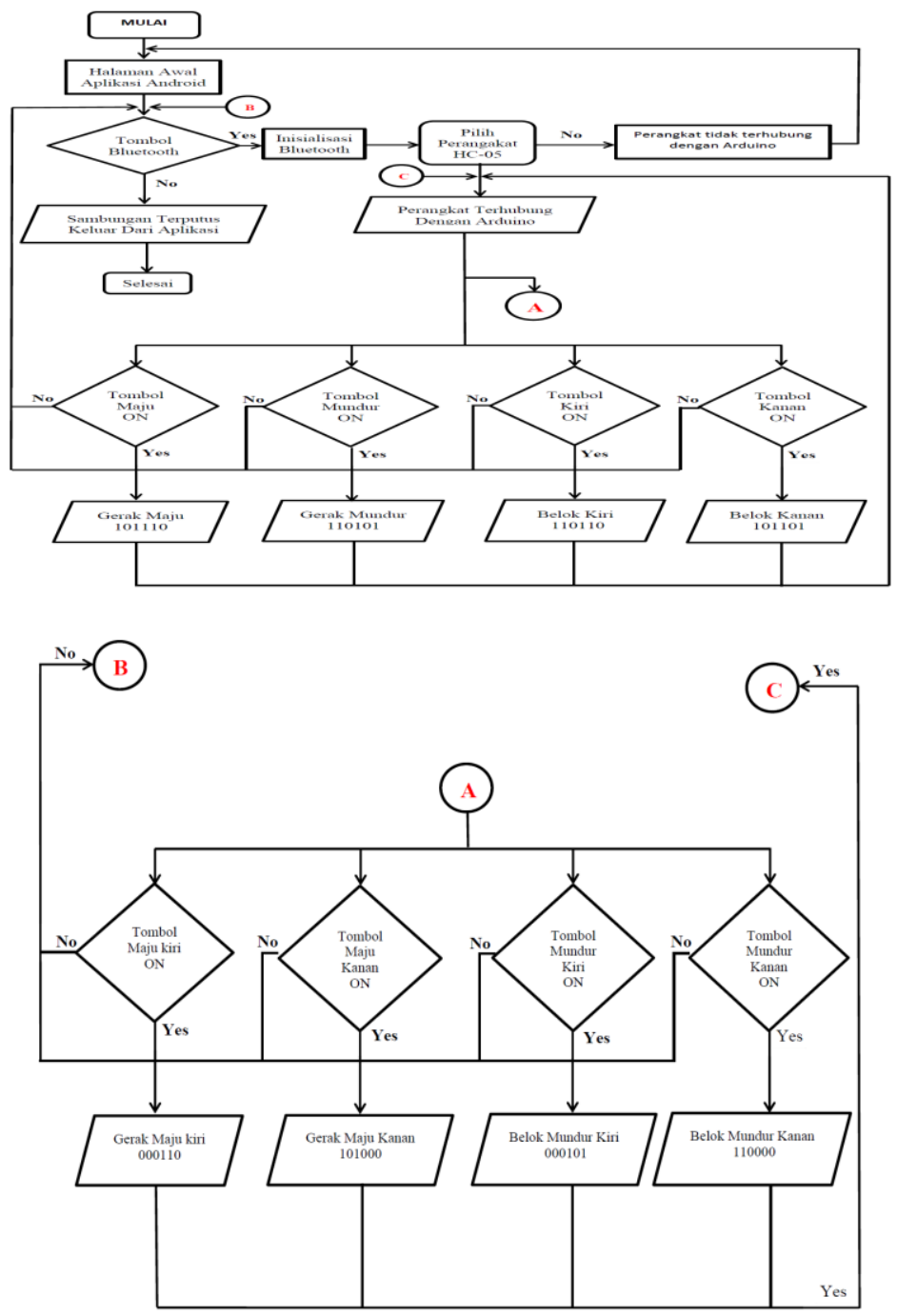

- Gambar 6 Algoritma Dan Flowchart Pengujian Sistem

\section{Data Pengujian dan Analisa}

\section{PENGUJIAN DAN ANALISA}

Setelah seluruh sistem selesai diimplementasikan ke dalam bentuk perangkat keras dan perangkat lunak, selanjutnya dilakukan pengambilan sampel data untuk melihat hasil kerja sistem.

Pada pengujian ini juga digunakan arduino ATMega 328 yang telah dimasukan program, untuk memberikan kondisi tertentu (high atau low) pada kaki input L298 sehingga kedua motor dapat bergerak. Di bawah ini adalah tabel perbandingan suplai tegangan dengan putaran yang dihasilkan tanpa beban :

- Tabel 1 Perbandingan Suplai Tegangan Dengan Putaran

\begin{tabular}{|c|c|c|c|c|c|c|c|}
\hline EN1 & IN1 & IN2 & EN2 & IN3 & IN4 & $\begin{array}{c}\text { ARAH } \\
\text { PUTARAN } \\
\text { MOTOR 1 }\end{array}$ & $\begin{array}{c}\text { ARAH } \\
\text { PUTARAN } \\
\text { MOTOR 2 }\end{array}$ \\
\hline 1 & 0 & 1 & - & - & - & CCW & \\
\hline 1 & 1 & 0 & - & - & - & CW & \\
\hline 0 & 1 & 0 & - & - & - & STOP & \\
\hline- & - & - & 1 & 0 & 1 & & CCW \\
\hline- & - & - & 1 & 1 & 0 & & CW \\
\hline- & - & - & 0 & 0 & 1 & & STOP \\
\hline
\end{tabular}

Keterangan :

$\mathrm{CW}=$ Clockwise (berputar searah jarum jam)

$\mathrm{CCW}=$ Counter Clockwise (berputar berlawanan arah jarum jam) 
Stop = berhenti

Berdasarkan hasil pengujian, untuk mengontrol gerakan serta kendali dari rancangan prototipe alat angkut helikopter ini, jika EN1 dan IN2 juga diberi logika 1, maka motor 1 berputar searah jarum jam (clockwise). Putaran ini digunakan untuk menggerakan roda kiri maju ke depan. Sedangkan jika EN1 dan IN1 diberi logika 1 maka motor 1 berputar berlawanan arah jarum jam (counter clockwise). Putaran ini digunakan untuk menggerakan roda kiri mundur ke belakang. Selanjutnya untuk menghentikan motor 1, maka hanya IN1 saja yang diberi logika 1. Begitu juga saat motor 2 menggerakan roda kanan.

\section{Data Kondisi Alat Angkut Dengan Masukan Sinyal Logic}

Pengujian ini menggunakan Arduino Atmega328 yang telah dimasukan program, untuk memberikan logika 1 (high) dan logika 0 (low) pada kaki input motor driver shield IC L298D maka kondisi motor DC 1 dan motor DC 2 dapat bergerak Clockwise (berputar searahjarum jam dan Counter Clockwise (berputar berlawanan arahjarum jam). Berikut tabel hasil pengujian kondisi pergerakan dari prototipe :

- Tabel 2 Pengujian Kondisi Pergerakan Dari Prototipe

\begin{tabular}{|c|c|c|c|c|c|l|}
\hline \multicolumn{3}{|c|}{ MOTOR 1 } & \multicolumn{3}{c|}{ MOTOR 2 } & \multirow{2}{*}{$\begin{array}{c}\text { PERGERAKAN } \\
\text { PROTOTIPE }\end{array}$} \\
\hline EN1 & IN1 & IN2 & EN2 & IN3 & IN4 & \\
\hline 1 & 0 & 1 & 1 & 1 & 0 & MAJU \\
\hline 1 & 1 & 0 & 1 & 0 & 1 & MUNDUR \\
\hline 1 & 1 & 0 & 1 & 1 & 0 & BELOK KIRI \\
\hline 1 & 0 & 1 & 1 & 0 & 1 & BELOK KANAN \\
\hline 0 & 0 & 0 & 1 & 1 & 0 & MAJU KIRI \\
\hline 1 & 0 & 1 & 0 & 0 & 0 & MAJU KANAN \\
\hline 0 & 0 & 0 & 1 & 0 & 1 & MUNDUR KIRI \\
\hline 1 & 1 & 0 & 0 & 0 & 0 & MUNDUR KANAN \\
\hline
\end{tabular}

\section{Data Kondisi Motor DC Dengan Masukan Nilai Tegangan Dan Arus}

Pada penguat daya rancangan ini menggunakan sumber DC 9 Volt yang masing-masing di suplai secara terpisah ke komponen board arduino dan terminal external powermotor driver shield. Dengan memberikan nilai tegangan dan arus ke motor 1 dan Motor 2, maka diperoleh RPM ke dua motor DC seperti pada tabel di bawah ini :

Tabel 3.Kondisi Motor Dengan Pengukuran Nilai Tegangan (Volt) dan Hasil Pengukuran RPM (Revolution Per Minute)

\begin{tabular}{|c|c|c|c|c|c|}
\hline Speed & $\begin{array}{c}\text { PWM } \\
\text { Setting }\end{array}$ & $\begin{array}{c}\text { Motor 1 } \\
\text { (Volt) }\end{array}$ & $\begin{array}{c}\text { Motor 2 } \\
\text { (Volt) }\end{array}$ & $\begin{array}{c}\text { RPM } \\
\text { motor 1 }\end{array}$ & $\begin{array}{c}\text { RPM } \\
\text { motor 2 }\end{array}$ \\
\hline 0 & 0 & 0 & 0 & 0 & 0 \\
\hline 1 & 90 & 5,77 & 5,77 & 63,9 & 64,1 \\
\hline 2 & 110 & 6,13 & 6,13 & 67,3 & 67,4 \\
\hline 3 & 130 & 7,05 & 7,05 & 70,7 & 70,6 \\
\hline 4 & 150 & 7,09 & 7,09 & 71,7 & 71,7 \\
\hline 5 & 170 & 7,14 & 7,14 & 72,8 & 72,8 \\
\hline 6 & 190 & 7,19 & 7,19 & 73,9 & 74,2 \\
\hline 7 & 210 & 7,21 & 7,21 & 75,8 & 75,0 \\
\hline 8 & 230 & 7,24 & 7,24 & 76,0 & 76,1 \\
\hline 9 & 255 & 7,32 & 7,32 & 76,8 & 76,4 \\
\hline
\end{tabular}


- Tabel 4 Kondisi Motor Dengan Pengukuran Nilai Arus (Amp)

\begin{tabular}{|c|c|c|c|}
\hline Speed & $\begin{array}{c}\text { PWM } \\
\text { Settimg }\end{array}$ & $\begin{array}{c}\text { Motor 1 } \\
\text { (Amp) }\end{array}$ & $\begin{array}{c}\text { Motor 2 } \\
\text { (Amp) }\end{array}$ \\
\hline 0 & 0 & 0 & 0 \\
\hline 1 & 90 & 0,02 & 0,02 \\
\hline 2 & 110 & 0,02 & 0,02 \\
\hline 3 & 130 & 0,02 & 0,02 \\
\hline 4 & 150 & 0,02 & 0,02 \\
\hline 5 & 170 & 0,02 & 0,02 \\
\hline 6 & 190 & 0,02 & 0,02 \\
\hline 7 & 210 & 0,02 & 0,02 \\
\hline 8 & 230 & 0,02 & 0,02 \\
\hline 9 & 255 & 0,02 & 0,02 \\
\hline
\end{tabular}

Pengukuran nilai arus (Amp), tegangan (Volt) dan RPM (Revolution Per Minute), dimulai dari pengaturan kecepatan (Speed) yang paling tinggi ke pengaturan kecepatan yang paling rendah dengan kondisi Kedua motor DC tanpa beban.

Dengan perubahan nilai speed 0-9 yang sudah diprogram, maka variasi PWM pada program arduino adalah $0_{\min }-255_{\max }$ yang dimulai dengan speed 1 dengan nilai PWM setting pada 90 PWM, apabila pengaturan PWM $<90$ maka nilai tegangan output yang dihasilkan dari motor driver shield ke motor DC cenderung terlalu rendah $(<3$ Volt) untuk menggerakan motor DC tipe N20.

\section{KESIMPULAN}

Dari hasil perancangan alat hingga pengujian dan pembahasan sistem makadapat ditarik kesimpulan, antara lain :

1. Dari hasil pengujian kolaborasi sistem antara pengguna andriod, modul bluetooth, arduino dan motor DC pada kondisi kecepatanmaksimum PWM 255, maka tegangan input pada kedua motor DC adalah 7,32 V menghasilkan putaran 76,8 RPM pada motor 1 dan menghasilkan putaran 76,4 RPM pada motor 2. Pada kondisi kecepatanminimum dengan PWM 90, maka tegangan input pada kedua motor DC adalah 5,77 V menghasilkan putaran 63,9 RPM pada motor 1 dan 64,1 RPM pada motor 2. Sedangkan hasil pengukuran nilai arus disetiap kondisi kecepatan motor tanpa beban adalah $20 \mathrm{~mA}$.

2. Pengendalian menggunakan aplikasi smartphone android dengan pengaturan sembilan kecepatan yang sudah diprogram dianggap berhasil, karena semua perintah variasi kecepatan dari pengguna aplikasi dapat diemplementasikan melalui pengujian pairingbluetooth dengan mengontrol pergerakan prototipe alat angkut helikopter dari jarak maksimal 10,5 meter (tanpa halangan) dan dari 8 meter (dengan penghalang tembok) didapatkan koneksi Bluetooth HC-05 dengan perangkat android tetap stabil.

3. Hasil pengukuran jarak antara rangka dan landasan adalah $15 \mathrm{~mm}$. Dengan demikian, jarak yang dibutuhkan sudah sesuai ukuran yang diharapkan untuk mengimplementasikan roda penggerak ke bagian rangka.

\section{DAFTAR PUSTAKA}

[1]. Aviation Supplies And Academyc, dictionary of aeronautical, 2016, fourth edition.

[2]...Diytechdotnet,2013,https://diytechdotnet.wordpress.com/2013/10/09/mengenalbluetooth-modul-hc-05-1/ diakses pada tanggal 03 Maret 2018.

[3]. Widodo Budiharto, 2014, Robotika Moderen-Torsi Dan Implementasi (Edisi Revisi), Yogyakarta : CV Andi Offset.

[4]. Evaristus Chandler Sunarto And M. Zakie A.H, 2016, Tow Bar Operating Procedure Bell 412 EP Doc No: DOC-002-021, Jakarta: Maintenance Department Travira Air.

[5]. Firmansyah Safitri, 2015, Proyek Robotika Kontrol Dengan Arduino, Jakarta : PT. Elios Media Kompurindo.

[6]. M. Aldo Aditya Nugroho, 2018, http://robotika.unit.itb.ac.id/main/950kontrol-motor-dc-menggunakanarduino-danmotor-driver.html diakses pada tanggal 30 Juni 2018.

[7].Lady ada, 2015, https://learn.adafruit.com/adafruit-motor-shield/2015/06/07/adafruit-usermanual.pdf/ diakses pada tanggal 28 Mei 2018.

[8]. Muhamad Andi Prasetyo, 2015, http://www.boarduino.web.id/2015/06/mengontrol-motor-dc-denganarduino-dan.htmldiakses pada tanggal 18 Maret 2018. 
[9]. Ramadhan Dwi Pratama, 2017, Rancang Bangun Sistem Kendali Robot Mobil Untuk Parkir Otomatis Dan Dapat Mendeteksi Obstacle Berbasis Mikrokontroler Arduino Mega 2560, Skripsi. Univesitas Lampung, Bandar Lampung. 